\title{
HUBUNGAN ANTARA ORIENTASI RELIGIUS DENGAN MOTIVASI MENGEKSPRESIKAN PRASANGKA DI MEDIA SOSIAL
}

\author{
Chairunnisa Sofia ${ }^{1}$, Nuri Sadida ${ }^{2}$ \\ ${ }^{1,2}$ Fakultas Psikologi, Universitas YARSI, Jakarta, Indonesia \\ Email: nuri.sadida@yarsi.ac.id ${ }^{1,2}$
}

\begin{abstract}
People are increasingly using the internet to access social media because it offers ease in various aspects. However, on the other hand, there is a negative impact from accessing and reading information using the internet, for the social media content fueled with hate speech of SARA (Ethnicity, Religion, Race, and Between Groups). The activity of spreading hate speech itself is an act of prejudiced expression. Therefore, this study aims to determine the relationship between religious orientation and motivation to express prejudice on social media. Participants in this study were 258 late adolescents aged 18-22 years and active social media users, obtained using the accidental sampling technique. The data tool in this research is a questionnaire. The Revised Religiosity Orientation Scale instrument is used to measure the dimensions of intrinsic and extrinsic religiosity, and The Motivation to Express Prejudice scale to measure motivation to express prejudice. Both of these measuring instruments have a good degree of reliability. From the results of data processing using Pearson's display, it was found that the two dimensions of religious orientation were significantly correlated with the motivation to express prejudice. On the intrinsic religious orientation dimension $(r=0.139, \mathrm{p}<0.05)$ and on the extrinsic religious orientation dimension $(\mathrm{r}=0.263, \mathrm{p}<0.05)$. The results of this study can be used as a reference for what if social media is to avoid the prejudice that can lead to various conflicts.
\end{abstract}

Keywords: Motivation To Express Prejudice, Religious Orientation, Social Media

\begin{abstract}
Abstrak: Internet semakin banyak digunakan masyarakat untuk mengakses media sosial karena menawarkan kemudahan bagi masyarakat dalam berbagai aspek. Namun di sisi lain, terdapat dampak negatif dari kemudahan mengakses dan menyebarkan informasi dengan penggunaan internet yaitu makin meningkatnya konten berisi ujaran kebencian dengan konten SARA. Aktivitas penyebaran ujaran kebencian sendiri merupakan tindakan mengekspresikan prasangka. Oleh karena itu, penelitian ini bertujuan untuk mengatahui hubungan orientasi religius dengan motivasi mengekspresikan prasangka di media sosial. Partisipan dalam penelitian ini sebanyak 258 remaja akhir berumur 18-22 tahun, dan pengguna media sosial aktif, diperoleh dengan menggunakan teknik accidental sampling. Alat pengumpulan data pada penelitian ini adalah kuesioner. Alat ukur yang digunakan yaitu Religiousity Orientation Scale-Revised untuk mengukur orientasi religius dimensi intrinsik dan ekstrinsik dan Motivation Express to Prejudice untuk mengukur motivasi mengekpresikan prasangka. Kedua alat ukur ini memiliki derajat reliabilitas yang baik. Dari hasil pengolahan data menggunakan korelasi Pearson, ditemukan bahwa kedua dimensi orientasi religius berkorelasi signifikan dengan motivasi mengekspresikan prasangka. Pada dimensi orientasi religius intrinsik $(r=0,139, p<0,05)$ dan pada dimensi orientasi religius ekstrinsik $(\mathrm{r}=0,263, \mathrm{p}<0,05)$. Hasil penelitian ini dapat dijadikan rujukan untuk bagaimana bersikap di media sosial agar terhindar dari prasangka yang dapat menimbulkan berbagai konflik.
\end{abstract}

Kata Kunci: Media Sosial, Motivasi Mengekspresikan Prasangka, Orientasi Religius

\section{PENDAHULUAN}

Internet semakin banyak digunakan di seluruh dunia, termasuk di Indonesia. Pada tahun 2017, survei Asosiasi Penyelenggara Jasa Internet Indonesia (APJII) melaporkan bahwa jumlah pengguna internet di Indonesia mencapai 143,26 juta jiwa yaitu lebih dari $50 \%$ populasi rakyat Indonesia (Setiawan, 2018). Pengguna internet terbanyak berumur 15-19 tahun 91\% dan 20-24 tahun 88,5\% (APJII, 2017). Alasan tertinggi penggunaan internet adalah untuk mengakses media sosial yaitu sebesar 19,1\%. Internet memiliki dampak positif dalam berbagai aspek misalnya membuat pengguna lebih mudah untuk 
memperoleh informasi, mengekspresikan dan mendapatkan manfaat sosial dan ekonomi (Amin dkk., 2018). Namun di sisi lain, terdapat dampak negatif internet yaitu mudahnya berkembang informasi bersifat diskriminatif yang ada di media sosial (Chao, 2015). Informasi diskriminatif dapat berbentuk berita bohong (hoax), penyebaran ujaran kebencian (hate speech), kriminalitas dunia maya (cyber crime), penyebaran tindakan rasisme dunia maya (cyber racism), penindasan atau perundungan dunia maya (cyber bullying), radikalisasi dunia maya (cyber radicalization) (Amin dkk., 2018).

Fenomena ini juga terjadi pada media sosial di Indonesia, dimana konten bermasalah yang banyak tersebar adalah penyebaran ujaran kebencian di dunia maya (cyber hate) dengan tema rasisme. Laporan Kepala Subdit IT dan Cyber Crime Polri, menjelaskan bahwa konten ujaran kebencian SARA merupakan tindakan pidana yang paling banyak diadukan ke polisi (Movanita, 2017). Tingginya penyebaran cyber hate yang bersifat rasisme dapat memengaruhi perilaku pribadi maupun kolektif untuk memicu komentar dan perdebatan rasis di media sosial, serta mendorong suatu kelompok untuk melakukan tindakan kekerasan (Blee, 2007; Jubany \& Roiha, 2015).

Hate speech dapat didefinisikan sebagai ekspresi dari kebencian terhadap individu atau kelompok sosial berdasarkan keanggotaan dalam kelompok tertentu, misalnya ras, etnis, kebangsaan, agama, kecacatan, jenis kelamin atau orientasi seksual mereka (Bojarska, 2018). Berdasarkan definisi tersebut, dapat disimpulkan bahwa aktivitas menyebarkan ujaran kebencian merupakan tindakan mengekspresikan prasangka. Prasangka adalah sebuah sikap (biasanya negatif) terhadap anggota kelompok tertentu, semata-mata didasarkan pada keanggotaan mereka dalam kelompok tersebut (Baron \& Byrne, 2004). Pada remaja, prasangka sudah menjadi lebih permanen sehingga usaha untuk mengubah persepsi yang negatif tentang orang lain menjadi hal yang susah (Suprapto, 2018). Terdapat dua bentuk dari ekspresi prasangka, yaitu subtle (tersembunyi) dan blatant (terang-terangan) (Brown, 2005).

Penelitian menyatakan bahwa prasangka yang diekspresikan secara sengaja didorong oleh motivasi yang ada pada diri individu atau sebuah kelompok untuk mengungkapkan prasangka kepada individu atau kelompok lain, terutama ketika mereka dapat dengan bebas mengekspresikan prasangka (Plant \& Devine, 2009). Selain itu, ekspresi prasangka juga dapat disebabkan adanya dorongan dari lingkungan sosial untuk mengekspresikan prasangka (Forscher dkk., 2015). Lebih lanjut, terdapat dua jenis dorongan yang mempengaruhi motivasi seseorang untuk mengekspresikan prasangka, yaitu internal motivation to express prejudice (IMP) atau dorongan untuk berprasangka yang bersumber dari internal diri dan external motivation to express prejudice (EMP) yaitu dorongan untuk berprasangka yang bersumber dari eksternal diri.

Isu ujaran kebencian yang sempat menjadi isu nasional dan berpotensi memicu konflik sosial adalah beberapa isu provokatif seperti isu munculnya kembali PKI, penjemputan paksa ulama, serta pengrusakan nama baik presiden atau figur publik (Matondang, 2018). Terdapat pula pihak yang menamakan diri sebagai pembela Islam dan menyebarkan ujaran kebencian dengan topik terkait agama Islam dan pemimpin agama Islam yang menyebarkan hashtag pada media sosial seperti "\#RakyatBersamaFPI, \#MuslimBersatu, \#JanganPilihPartaiPenistaAgama” (Juniarto, 2018). Hal ini digunakan 
oleh banyak pihak yang tidak menginginkan seseorang yang bukan dari agama Islam dicalonkan kembali ke posisi gubernur DKI untuk periode 2017 hingga 2022. Alasan bahwa haram hukumnya mencalonkan pemimpin yang bukan beragama Islam menjadi isu utama yang diangkat pihak-pihak tertentu yang tidak ingin lawan politiknya yang bukan bergama Islam menang atau terpilih (Hutabarat \& Panjaitan, 2017).

Adapun prasangka sosial antar kelompok dalam kehidupan bermasyarakat menyebabkan intoleransi (Muhid \& Fadeli, 2018). Penelitian menyatakan bahwa terdapat lebih dari $70 \%$ kelompok agama menggunakan agama bukan untuk kepentingan agama itu sendiri, sehingga menyebabkan intoleransi dan kekerasan agama. Lebih lanjut dalam penelitian tersebut, disebutkan bahwa konflik akibat adanya prasangka yang terjadi antar umat beragama, bukan berasal dari agama, melainkan dari orientasi beragama atau orientasi religius yang tidak tepat. Hal ini karena ajaran agama selalu baik atau mulia, maka menjadi tidak tepat apabila ajaran agama menjadi sumber tindakan kekerasan dan kejahatan (Hutabarat \& Panjaitan, 2017).

Orientasi religius adalah cara individu memahami ajaran agamanya dan bagaimana individu tersebut mengaplikasikan ajaran agama sebagai panduan kehidupan sehari-hari (Allport \& Ross, 1967). Orientasi religius terbagi menjadi orientasi ekstrinsik dan intrinsik. Menurut penelitian, terdapat perbedaan level prasangka terhadap penganut agama lain berdasarkan orientasi keberagamaan penganut agama tersebut, dimana prasangka menjadi lebih tinggi ketika responden memiliki orientasi keberagamaan ekstrinsik dibandingkan responden dengan orientasi intrinsik (Wibisono, 2012). Penelitian lainnya menyatakan bahwa seseorang dengan orientasi intrinsik umumnya tidak menyimpan prasangka kepada orang lain, sedangkan seseorang dengan orientasi ekstrinsik lebih mungkin memendam prasangka terhadap pemeluk agama yang lain (Wrench dkk., 2006).

Penelitian-penelitian diatas menunjukan bahwa seseorang yang memiliki orientasi religius ekstrinsik memiliki kecenderungan berprasangka lebih tinggi bila dibandingkan dengan seseorang yang memiliki orientasi religius intrinsik. Hal ini dikarenakan individu dengan orientasi religius ekstrinsik lebih memahami agama untuk menunjang motif-motif lain seperti status yang lebih tinggi, munculnya rasa aman atau harga diri (Wibisono, 2012). Orang yang menganut orientasi religius ekstrinsik, melaksanakan bentuk-bentuk ritual keagamaan, shalat, seperti berpuasa, haji, dan sebagainya namun mereka tidak benar-benar menghayatinya (Barrett dkk., 2005). Sedangkan orang dengan orientasi religius intrinsik menjadikan ajaran agama sebagai kebutuhan atau motif utama. Individu dengan orientasi religius intrinsik mampu membangun harmonisasi antara keyakinan agama dengan konteks lingkungannya, dan individu yang memiliki orientasi religius intrinsik yang tinggi mampu menyeimbangkan antara keyakinan dan perilaku keberagamaan dalam hidupnya.

Berbagai literatur tersebut menunjukkan bahwa orientasi religius ekstrinsik memiliki korelasi yang positif dengan terbentuknya prasangka sedangkan orientasi religius intrinsik memiliki korelasi yang negatif dengan terbentuknya prasangka. Akan tetapi, belum ditemukan dalam literatur apakah tipe orientasi religius seseorang berhubungan dengan motivasi seseorang untuk mengekpresikan prasangka di media sosial. Maka penelitian ini bertujuan untuk melihat hubungan orientasi religius dengan 
motivasi mengekspresikan prasangka di media sosial. Terdapat dua hipotesis yang diteliti dalam penelitian ini. Hipotesis pertama adalah "Terdapat hubungan negatif antara orientasi religius intrinsik (I) dengan motivasi mengekspresikan prasangka (MP)". Hipotesis kedua adalah "Terdapat hubungan positif antara orientasi religius intrinsik (E) dengan motivasi mengekspresikan prasangka (MP)".

\section{LANDASAN TEORI}

\section{Orientasi Religius}

Orientasi religius adalah cara individu memahami ajaran agamanya dan bagaimana individu tersebut mengaplikasikan ajaran agama sebagai panduan kehidupan sehari-hari (Allport \& Ross, 1967). Kemudian, tipologi psikologis orientasi religius dibagi ke dalam klasifikasi intrinsik dan ekstrinsik. Seseorang dengan orientasi religius intrinsik menjadikan agama sebagai tujuan hidup (terminal value) yaitu sebagai pemandu dan pengatur seluruh hidup. Seseorang yang memiliki orientasi religius intrinsik cenderung memahami agama sebagai kebutuhan diri dan termotivasi oleh iman kepada-Nya. Seorang yang memiliki orientasi religius intrinsik memiliki kesadaran tinggi untuk melaksanakan ibadah atau berperilaku dengan mengacu ajaran agama, dan motivasi tersebut timbul dari dalam dirinya, bukan terdorong oleh kebutuhan untuk memiliki status sosial yang tinggi atau pengakuan dari orang lain (Feist, 2008).

Sedangkan seseorang dengan orientasi ekstrinsik menggunakan agama untuk mencukupi tujuan dan kebutuhan lain (instrumental value) demi kepentingankepentingannya sendiri. Orang yang berorientasi religius ekstrinsik tidak menggunakan iman demi kepentingan pribadi, ekonomi, sosial atau kepentingan selain iman. Bagi individu dengan orientasi ini, ajaran agama adalah cara untuk mendapatkan kehangatan dan perlindungan dalam menjalani tantangan kehidupan yang sulit (Tahaha \& Rustan, 2017).

Lebih lanjut prasangka didefinisikan sebagai sebuah sikap (biasanya negatif) terhadap anggota kelompok tertentu, semata-mata didasarkan pada keanggotaan mereka dalam kelompok tersebut (Baron \& Kenny, 1986). Prasangka juga biasanya berdasar pada penilaian awal yang sering kali dilakukan sebelum seseorang mengetahui banyak tentang karakteristik orang lain. Terdapat dua bentuk dari ekspresi prasangka, yaitu subtle (tersembunyi) dan blatant (terang-terangan) (Caroli dkk., 2013).

\section{Motivasi Ekspresi Prasangka Di Media Sosial}

Fenomena seperti hoax, hate speech, cyber crime, cyber racism, cyber bullying, cyber radicalization menjelaskan bahwa seseorang mengekspresikan prasangka secara sengaja karena adanya motivasi yang ada pada diri individu atau sebuah kelompok untuk mengungkapkan prasangka kepada individu atau kelompok lain, terutama ketika mereka dapat dengan bebas mengekspresikan prasangka tersebut (Plant \& Devine, 2009). Motivasi mengekspresikan prasangka dapat berasal dari internal diri, misalnya keyakinan atau nilai yang dianut oleh diri, dapat juga bersumber dari eksternal diri, misalnya keyakinan atau nilai yang dianut oleh orang lain (Forscher dkk., 2015). 
Kaitan antara orientasi religius dan motivasi mengekspresikan prasangka di media sosial dapat terjadi dengan melihat beberapa faktor, seperti identifikasi seseorang dengan norma kelompok sosial dan tingkat entitativitas dan kohesivitas kelompok. Ketika seseorang menjadi anggota kelompok sosial dan norma dalam suatu kelompok mendukung toleransi rasial, seseorang dengan identifikasi yang kuat terhadap kelompok akan cenderung menunjukkan toleransi. Sedangkan ketika norma dalam kelompok mendukung prasangka, maka anggota dengan identifikasi yang kuat dengan kelompok akan cenderung menunjukkan prasangka (Crandall \& Eshleman, 2003). Hal ini juga berlaku untuk identifikasi seseorang dengan kelompok religius. Seperti misalnya pada penganut agama yang mengidentifikasi diri dengan norma kelompok, ketika normanorma sosial dalam kelompok mendukung prasangka, anggota kelompok menunjukkan tingkat prasangka individu yang sangat tinggi.

Ketika seseorang yang memiliki orientasi religius ekstrinsik berada dalam kelompok yang kohesivitas dan entitativitasnya tinggi, maka ia cenderung termotivasi untuk mengekspresikan prasangka ketika kelompoknya mengekspresikan prasangka (Effron \& Knowles, 2015). Menurut penelitian (Sparks \& Gore, 2017), seseorang dengan orientasi ekstrinsik lebih mudah mengikuti pengaruh dari kelompok sosialnya. Sedangkan seseorang yang memiliki orientasi religius intrinsik, dengan sadar melaksanakan ibadah atau berperilaku sesuai ajaran agama, dimana motivasi tersebut timbul dari dalam diri dan bukan karena didorong oleh keinginan memperoleh status sosial, atau mendapat pengakuan dari orang lain.

Semakin seseorang mengidentifikasikan dirinya dengan norma in-group, maka ia juga akan semakin termotivasi mengekspresikan prasangka ketika kelompoknya juga mengekspresikan prasangka. Menurut penelitian, seseorang dengan orientasi ekstrinsik lebih mudah mengidentifikasikan dirinya dengan kelompoknya, sedangkan orang-orang yang memiliki orientasi religius intrinsik cenderung dapat mengidentifikasikan diri pada seluruh umat manusia dengan baik (Sparks \& Gore, 2017). Ketika seseorang dapat mengidentifikasi diri dengan seluruh umat manusia dengan baik, mereka membiarkan diri mereka terpapar dengan pengalaman baru lintas budaya. Dengan melakukan itu, mereka dapat membuka diri ke berbagai sumber informasi dan mempelajari beragam norma budaya yang ada.

\section{METODE PENELITIAN}

Penelitian ini adalah penelitian korelasional karena penelitian yang akan dilakukan bertujuan untuk melihat dan mengetahui tingkat hubungan antara dua variabel, yaitu Orientasi Religius dan Motivasi Mengekspresikan Prasangka pada pengguna media sosial yang berusia 18-22 tahun. Partisipan direkrut dengan teknik accidental sampling dan partisipan yang berpartisipasi sebanyak 258 orang

\section{Pengukuran}

Untuk mengukur Orientasi Religius, peneliti mengadaptasi skala ROS-R (Religiousity Orientation Scale-Revised) (Gorsuch, 1988). Orientasi religius yang dimiliki subjek penelitian dapat diketahui dari total skor masing-masing dimensi pada skala ROS-R (Religiousity Orientation Scale-Revised). Alat ukur ini melihat orientasi religius seseorang, bergantung kepada seberapa setuju seseorang terkait bagaimana 
dirinya hidup dengan keyakinan agamanya. Apabila skor yang didapat pada salah satu dimensi lebih tinggi, maka mengindikasikan kecenderungan seseorang dalam orientasi religiusnya. Dalam alat ukur ini terdapat dua dimensi yang diukur yaitu Intrinsic (I) dan Extrinsic (E). Jumlah item pada alat ukur ini adalah 14 item. Seluruh item pada skala orientasi religiusitas diukur dengan menggunakan skala likert dari 1 (sangat tidak sesuai) sampai 5 (sangat sesuai).

Sementara untuk mengukur motivasi mengekspresikan prasangka di media sosial, peneliti mengadaptasi Motivation to Express Prejudice Scale (MP) yang dikembangkan oleh Forscher dkk., (2015). Terdapat dua dimensi yang diukur dalam kuesioner ini yaitu internal motivation to express prejudice (IMP) dan exsternal motivation to express prejudice (EMP). Jumlah item pada alat ukur ini adalah 12. Item pada skala motivasi mengekspresikan prasangka diukur dengan menggunakan skala likert dari 1 (sangat tidak setuju) sampai 9 (sangat setuju). Setelah dilakukan pengumpulan data, peneliti melakukan uji reliabilitas alpha cronbach kedua alat ukur.

\section{Metode Analisis Data}

Dalam melakukan analisis data, peneliti melakukan beberapa tahapan uji analisis data, dimulai dari uji distribusi normal menggunakan teknik kolmogorov-smirnov. Hasil uji distribusi normal ini kemudian digunakan untuk menentukan apakah analisis data menggunakan teknik korelasi Pearson Product Moment atau Spearman Rank.

\section{HASIL DAN PEMBAHASAN}

Dari uji korelasi yang dilakukan, dapat diketahui hasilnya pada tabel dibawah ini.

Tabel 1. hasil uji korelasi orientasi religius dengan dengan motivation to express prejudice $(\mathrm{MP})$

\begin{tabular}{llccc}
\hline & \multicolumn{1}{c}{$\mathrm{r}_{\mathrm{s}}$} & Sig. \\
\hline $\begin{array}{l}\text { Orientasi Religius Intrinsik (I) Motivation to Express } \\
\text { Prejudice (MP) }\end{array}$ & $0,139 *$ & 0,026 \\
$\begin{array}{l}\text { Orientasi Religius Ekstrinsik (E) Motivation to Express } \\
\text { Prejudice (MP) }\end{array}$ & $0,263 * *$ & 0,000 \\
\hline
\end{tabular}

Berdasarkan pada tabel diatas, uji korelasi antara dimensi Orientasi Religius Intrinsik (I) dengan Motivation to Express Prejudice (MP) menunjukkan hasil bahwa Orientasi Religius Intrinsik (I) secara signifikan berkorelasi dengan Motivation to Express Prejudice (MP) $(r=0,139, p<0,05)$. Maka semakin tinggi Orientasi Religius Intrinsik (I) semakin tinggi pula Motivation to Express Prejudice (MP) pada seseorang.

Selanjutnya, uji korelasi antara dimensi Orientasi Religius Ekstrinsik (E) dengan Motivation to Express Prejudice (MP) menunjukkan hasil bahwa Orientasi Religius Intrinsik (E) secara segnifikan berkorelasi dengan Motivation to Express Prejudice (MP) $(r=0,263, p<0,05)$. Maka semakin tinggi Orientasi Religius Ekstrinsik (E) semakin tinggi pula Motivation to Express Prejudice (MP) pada seseorang.

Hasil penelitian ini tidak konsisten dengan penelitian sebelumnya yang menyatakan bahwa orang dengan orientasi religius intrinsik cenderung tidak memendam prasangka kepada orang lain, sedangkan orang dengan orientasi religius ekstrinsik cenderung untuk 
memendam prasangka terhadap pemeluk agama lain (Wrench dkk., 2006). Perbedaan hasil penelitian ini dengan penelitian sebelumnya dapat disebabkan karena menurut hasil pengisian kuesioner, sebagian besar partisipan membayangkan kelompok LGBT sebagai objek prasangka dan bukan pemeluk agama lain.

Selain itu, Hasil penelitian ini sejalan dengan penelitian sebelumnya yang menyatakan bahwa orang dengan orientasi religius ekstrinsik cenderung untuk memendam prasangka terhadap pemeluk agama lain (Wrench dkk., 2006). Seseorang dengan orientasi religius eksternal menjalankan aktivitas agama untuk menunjang kebutuhan seperti status, rasa aman, dan harga diri, dimana orang dengan orientasi tersebut akan lebih mengikuti norma yang berlaku di lingkungannya (Wibisono, 2012). Apabila norma ekspresi prasangka tinggi di lingkungannya, maka seseorang dengan tipe seperti ini juga akan cenderung mengikuti norma tersebut. Menurut penelitian, seseorang dengan orientasi ekstrinsik lebih mudah mengikuti pengaruh dari kelompok sosialnya (Sparks \& Gore, 2017). Ketika seseorang yang memiliki orientasi religius ekstrinsik berada dalam grup yang kohesivitas dan entitativitasnya tinggi, maka ia cenderung termotivasi untuk mengekspresikan prasangka ketika kelompoknya mengekspresikan prasangka (Effron \& Knowles, 2015). Apabila norma ekspresi prasangka tinggi di lingkungannya, maka seseorang dengan orientasi religius ekstrinsik juga akan cenderung mengikuti norma tersebut.

Dari pembahasan diatas dapat disimpulkan bahwa terdapat faktor-faktor yang mempengaruhi hubungan positif antara orientasi religius dengan motivasi mengekspresikan prasangka di media sosial, misalnya identitas sosial. Adapun keterbatasan dalam penelitian ini adalah tidak menyertakan variabel-variabel yang mungkin menyambung hubungan antara orientasi religius dan motivasi mengekspresikan prasangka, seperti identitas sosial.

\section{KESIMPULAN}

Dari hasil penelitian ini, dapat disimpulkan bahwa terdapat hubungan positif yang signifikan antara orientasi religius intrinsik maupun ekstrinsik dengan motivasi mengekspresikan prasangka, dengan nilai korelasi orientasi religius ekstrinsik lebih tinggi dibandingkan orientasi religius intrinsik dengan motivasi mengekspresikan prasangka. Artinya, semakin sesorang memiliki orientasi religius intrinstik atau ekstrinsik maka semakin tinggi pula motivasi mengekspresikan prasangkanya, namun semakin ekstrinsik orientasi beragama seseorang, maka semakin besar kemungkinannya untuk mengekspresikan prasangka pada orang-orang yang dianggapnya melanggar nilai-nilai pribadi yang dianutnya. Sedangkan keterbatasan penelitian ini adalah tidak menyertakan variabel seperti identitas sosial untuk menghubungkan orientasi religius dan motivasi mengekspresikan prasangka.

\section{DAFTAR PUSTAKA}

Allport, G. W., \& Ross, J. M. (1967). Personal religious orientation and prejudice. Journal of Personality and Social Psychology, 5(4), 432-443. https://doi.org/10.1037/h0021212 
Amin, K., Alfarauqi, M. D. A., \& Khatimah, K. (2018). Social Media, Cyber Hate, and Racism. Komuniti, 10(1), 3-10. https://doi.org/10.23917/komuniti.v10i1.5613

APJII. (2017). Penetrasi dan perilaku pengguna internet Indonesia. Jakarta: APJII.

Baron, \& Byrne, D. (2004). Psikologi Sosial alih bahasa R. Medya, R. Djuwita, \& W. Kristiaji eds. Jakarta: Erlangga.

Baron, R. M., \& Kenny, D. A. (1986). The moderator-mediator variable distinction in social psychological research: Conceptual, strategic, and statistical considerations. Journal of Personality and Social Psychology, 51(6), 1173-1182. https://doi.org/10.1037/0022-3514.51.6.1173

Barrett, D. W., Patock-Peckham, J. A., Hutchinson, G. T., \& Nagoshi, C. T. (2005). Cognitive motivation and religious orientation. Personality and Individual Differences, 38(2), 461-474. https://doi.org/10.1016/j.paid.2004.05.004

Blee, K. M. (2007). The microdynamics of hate violence: Interpretive analysis and implications for responses. American Behavioral Scientist, 51(2), 258-270. https://doi.org/10.1177/0002764207306058

Bojarska, K. (2018). The Dynamics Of Hate Speech And Counter Speech In The Social Media Summary Of Scientific Research. Frankfurt: Centre for Internet and Human Rights.

https://cihr.eu/wp-content/uploads/2018/10/The-dynamics-of-hate-speech-andcounter-speech-in-the-social-media_English-1.pdf

Brown, R. (2005). Prejudice: Menangani Prasangka Dari Perspektif Psikologi Sosial. Yogyakarta: Pustaka Pelajar.

Caroli, M. E. De, Falanga, R., \& Sagone, E. (2013). Subtle and Blatant Prejudice Toward Chinese People in Italian Adolescents and Young Adults: The Role of "Friendship" and "Outgroup Representation". Procedia - Social and Behavioral Sciences, 82(3 July 2013), 74-80.

https://doi.org/10.1016/j.sbspro.2013.06.227

Chao, E.-C. (2015). The-Truth-About-Islam.Com: Ordinary Theories of Racism and Cyber Islamophobia. Critical Sociology, 41(1), 57-75. https://doi.org/10.1177/0896920513508662

Crandall, C. S., \& Eshleman, A. (2003). A justification-suppression model of the expression and experience of prejudice. Psychological Bulletin, 129(3), 414-446. https://doi.org/10.1037/0033-2909.129.3.414

Effron, D. A., \& Knowles, E. D. (2015). Entitativity and intergroup bias: How belonging to a cohesive group allows people to express their prejudices. Journal of Personality and Social Psychology, 108(2), 234-253. https://doi.org/10.1037/pspa0000020

Feist, G. J. (2008). Theories of personality (VI). Yogyakarta: Pustaka Pelajar.

Forscher, P. S., Cox, W. T. L., Graetz, N., \& Devine, P. G. (2015). The motivation to express prejudice. Journal of Personality and Social Psychology, 109(5), 791-812. https://doi.org/10.1037/pspi0000030

Gorsuch, R. L. (1988). Psychology of Religion. Annual Review of Psychology, 39(1), 201-221. https://doi.org/10.1146/annurev.ps.39.020188.001221

Hutabarat, B. A., \& Panjaitan, H. H. (2017). Tingkat Toleransi Antaragama di Masyarakat Indonesia. Societas Dei: Jurnal Agama Dan Masyarakat, 3(1), 8-34. https://doi.org/10.33550/sd.v3i1.28 
Jubany, O., \& Roiha, M. (2015). Backgrounds, Experiences and Responses to Online Hate Speech: A Comparative Cross-Country Analysis. Turin: UNICRI. http://www.unicri.it/special_topics/hate_crimes/Backgrounds_Experiences_and_Re sponses_to_Online_Hate_Speech_A_Comparative_Cross-Country_Analysis.pdf

Juniarto, D. (2018). The Muslim Cyber Army: what is it and what does it want? Indonesia at Melbourne. Melbourne: The University of Melbourne.

https://indonesiaatmelbourne.unimelb.edu.au/the-muslim-cyber-army-what-is-itand-what-does-it-want/

Matondang, D. B. (2018). Polisi: 'The Family MCA' Sebar Isu PKI Bangkit hingga Ulama Diculik. Jakarta: Detik News.

https://news.detik.com/berita/d-3888475/polisi-the-family-mca-sebar-isu-pkibangkit-hingga-ulama-diculik

Movanita, A. N. K. (2017). 2016, Konten Berisi Ujaran Kebencian Paling Banyak Diadukan ke Polisi. Jakarta: Kompas.com https://nasional.kompas.com/read/2017/03/26/08465611/2016.konten.berisi.ujaran. kebencian.paling.banyak.diadukan.ke.polisi

Muhid, A., \& Fadeli, M. I. (2018). Korelasi antara prasangka sosial dan toleransi beragama pada mahasiswa aktivis organisasi kemahasiswaan di perguruan tinggi umum. Al Qodiri, 15(2), 124-136. https://doi.org/10.1234/al\%20qodiri.v15i2.3191

Plant, E. A., \& Devine, P. G. (2009). The active control of prejudice: Unpacking the intentions guiding control efforts. Journal of Personality and Social Psychology, 96(3), 640-652. https://doi.org/10.1037/a0012960

Setiawan, S. R. (2018). Tahun 2017, Pengguna Internet di Indonesia Mencapai 143,26 Juta Orang. Jakarta: Kompas.com. https://ekonomi.kompas.com/read/2018/02/19/161115126/tahun-2017-penggunainternet-di-indonesia-mencapai-14326-juta-orang

Sparks, H., \& Gore, J. (2017). My Religion and My People: Levels of Ingroup Identification and Christian Religious Orientations. Kentucky Journal of Undergraduate Scholarship (KJUS), 1(1), 100-120. https://encompass.eku.edu/kjus/vol1/iss1/9

Suprapto, M. H. (2018). Anak dan Prasangka: Intervensi Terhadap Prasangka Sejak Dini. Seminar Nasional Psikologi, 194-206. http://hdl.handle.net/123456789/1218

Tahaha, H., \& Rustan, E. (2017). Orientasi Religiusitas dan Efikasi Diri dalam Hubungannya dengan Kebermaknaan Pendidikan Agama Islam pada Mahasiswa IAIN Palopo. Jurnal Studi Agama Dan Masyarakat, 13(2), 163-179. https://doi.org/10.23971/jsam.v13i2.551

Wibisono, S. (2012). Orientasi Keberagaman, Modal Sosial dan Prasangka terhadap Kelompok Agama Lain pada Mahasiswa Muslim. Jurnal Insani, 14(03), 136-148. http://journal.unair.ac.id/download-fullpapers-14-3-1.pdf

Wrench, J. S., Corrigan, M. W., McCroskey, J. C., \& Punyanunt-Carter, N. M. (2006). Religious Fundamentalism and Intercultural Communication: The Relationships Among Ethnocentrism, Intercultural Communication Apprehension, Religious Fundamentalism, Homonegativity, and Tolerance for Religious Disagreements. Journal of Intercultural Communication Research, 35(1), 23-44. https://doi.org/10.1080/17475740600739198 